\title{
Yield of Soybean in Different Systems of Pasture Replacement With and Without Soil Scarification
}

\author{
Luanda Torquato Feba ${ }^{1}$, Elcio Ricardo José de Sousa Vicente ${ }^{1}$, Luis Gustavo Torquato Feba ${ }^{1} \&$ Edemar Moro \\ ${ }^{1}$ Agrarian Department, University of Western São Paulo, Presidente Prudente, SP, Brazil \\ Correspondence: Luanda Torquato Feba, Agrarian Department, University of Western São Paulo, Raposo \\ Tavares Highway, km 572, Limoeiro Village, Code 19067-175, Presidente Prudente, SP, Brazil. E-mail: \\ lu_feba@hotmail.com
}

Received: January 24, 2018

Accepted: April 2, $2018 \quad$ Online Published: May 15, 2018

doi:10.5539/jas.v10n6p163

URL: https://doi.org/10.5539/jas.v10n6p163

\begin{abstract}
The objective of this work was to adjust the physical environment in sandy soils in no-tillage, to allow for the better development and yield of soybean, under water deficient conditions. The experiment was conducted at the Experimental Farm of The University of Western São Paulo in Presidente Bernardes, SP, 22 28 $28^{\prime} 09^{\prime \prime}$ S, 51 ${ }^{\circ} 67^{\prime} 48^{\prime \prime}$ W, $400 \mathrm{~m}$ asl. The experimental design constitued of two blocks each for the study variable: soil scarification, and no soil scarification. Each block was divided into 4 sub-blocks/treatments (control-natural seed bank of Urochloa brizantha-NSB; Urochloa brizantha broadcast seeding; Urochloa brizantha in line seeding; Urochloa brizantha in line seeding with soybean intercropped) with four replicates. As a plot, four systems of reimplantation of pasture with $4 \mathrm{~kg} \mathrm{ha}^{-1}$ of Urochloa brizantha (Marandu cv.). Evaluated parameters: dry matter yield of pasture; yield components and soybean yield. The variables analyzed in each treatment were submitted to analysis of variance ( $p$ $<0.05)$ and as means were compared by the Tukey test $(\mathrm{p}<0.05)$ using the Sisvar software. Considering the results obtained in the following research, it can be concluded that, according to the different pasture reimplatation systems, the treatment (in-line + soybean) contributed both to the increase of the dry matter of fodder, and to a yield of Soybean. Regarding the effect of soil scarification, none of the results were significantly influenced.
\end{abstract}

Keywords: consortium system, no-tillage, Urochloa brizantha (cv. Marandu)

\section{Introduction}

At no-tillage the desiccation of grasses has an effect on weeds, which are divided into three distinct aspects: the physical, the chemical, and the biological (R. A. Pitelli \& R. L. C. M. Pitelli, 2004). Monquero et al. (2009), emphasizes that, since the physical effect occurs in the germination interference and in the weed survival rate, the layer of mulch that remains on the ground prevents the sun's rays from reaching the seedlings and the seeds. The biological effect occurs with the installation of microbiocenosis in the superficial layer of the soil, this is composed of organisms capable of using seeds and weed seedlings as an energy source, this is due to the large amount of organic matter deposited in the soil. Lastly, the chemical effect, occurs through chemicals that are released by the mulch, which then causes allelopathy in these plants.

Therefore, the time of desiccation before planting becomes an important cultural management practice, since it can cause interference in the release of nutrients by the straw. Additionally, some studies have demonstrated the effect of plant residues on the mobility of cations in soil (Franchini et al., 2001; Miyazawa et al., 2002).

In regions which have a tropical climate the microorganisms responsible for the decomposition of vegetal remains, are favored by the temperature and high humidity. For this reason, vegetal remains decompose more rapidly, thus reducing the cover on the ground, in this way the ideal choice of species are those that are difficult to decompose (Alves et al., 1995).

It would be ideal, for a period of time to use the sowing of pastures in agricultural areas, since it physically improves the quality of the soils, as the residues of dry matter of the pasture allow the organic matter in the contents of the soil to recover to values similar to that of the original (Freitas et al., 2000; Wendling et al., 2005). The pasture is also advantageous for controlling weeds, nematodes and diseases, because the soil is always covered, causing organic matter increase and cycle break of the diseases (Asmus, 2005; Marchão et al., 2007; 
Toledo-Souza et al., 2008; Pacheco et al., 2009). According to Machado and Assis (2010), the most suitable grass species for forage and straw production for soil cover is U. brizantha.

In view of management, there is the unpacking of the ground using scarifiers, as they produce rougher surfaces than the disc implements (heavy grids), aiming to increase porosity, reduce density, and simultaneously break crusty surface layers and compacted subsurface layers (Kochhann \& Denardin, 2000). For this reason, scarification increases infiltration rates and the capacity to store water in the soil (Camara \& Klein, 2005). According to Reichert et al. (2009), scarification reduces soil mechanical resistance to penetration and enables root development.

The use of the scarifier creates a micro-relief on the soil surfaces and these changes affect the runoff and the temporary storage of water (Vazquez \& De Maria, 2003). Therefore, this implement provides a minimum soil surface rotation, thus reducing the risks of straw drag, even in more critical situations, and with less tractive effort, thus allowing the fast recovery of the pastures.

The sandy soils have low cation exchange capacity (CTC) and natural fertility, low $\mathrm{pH}$, aluminum in the subsoil and reduced organic matter (OM), low water retention capacity and high susceptibility to erosion.

Erosion, underground compaction, water loss, clay fraction dispersion and consequent drift or elution loss, are some of the problems caused by excessive mechanical management of these soils and can potentially trigger a desertification process, which begins with the loss of organic soil matter (Kluthcouski \& Cordeiro, 2016).

In relation to the culture studied, soybean has contributed to the country's trade balance, it has contributed to maintaining a positive economy for Brazil (Farias et al., 2001). A survey carried out by CONAB in the 2015/16 crop reported a significant gain in soybean yield in the state of São Paulo, it had a $11.6 \%$ growth compared to the previous crop, from $2,970 \mathrm{~kg} / \mathrm{ha}$ to $3,316 \mathrm{~kg} / \mathrm{ha}$.

Considering that soy is responsible for the emergence of Brazilian commercial agriculture (Dall'gnol, 2000), and the concept of agribusiness in Brazil (Brum et al., 2005). Soy is also the main oilseed produced and consumed both for animal use by soybean meal, and for human consumption by means of oil. In the world ranking, Brazil is the second largest producer and processor of soybeans, and also the second crop producer in the world ranking of soybean exporters (Silva, Lima, \& Batista, 2010).

In addition to having the potential to perform multiple functions in production systems, it generates products of high biological value; approximately $40 \%$ of the soybean cultivars are capable of fixing large amounts of nitrogen in the soil biologically (Hungria et al., 1994).

According to Câmara (2014), soybean is a noduliferous plant, and has roots that perform the natural functions, the roots establish a symbiotic relationship with bacteria that are able to fix nitrogen in the soil through biological fixation, this is responsible for $65 \%$ of the nitrogen deposited in the soil, worldwide (Hungria et al., 2001).

It is worth mentioning that porosity and soil aggregation can be improved when legumes are introduced into the planting system, because these legumes have a large amount of root (Igue, 1984). The objective of this work was to adjust the physical environment in sandy soils in no-tillage, to allow a better development and yield of soybean, even under water deficient conditions.

\section{Materials and Methods}

\subsection{Workplace and Studied Species}

The experiment was conducted at the Experimental Farm of University of Western São Paulo (UNOESTE) in Presidente Bernardes, SP, at $22^{\circ} 28^{\prime} 09^{\prime \prime}$ S, 51 $67^{\prime} 48^{\prime \prime}$ W, $400 \mathrm{~m}$ asl. According to the Brazilian Soil Classification System (Embrapa, 2006), the soil of the experimental area is classified as dystrophic Red Argisol, with smooth undulating relief.

The experimental area was occupied by Urochloa brizantha (cv Marandu) with 5 years of implantation, but with low forage production capacity and low animal support capacity.

The monthly data regarding rainfall and minimum and maximum temperature during the conduction of the experiment, collected from the Experimental Farm of University of Western São Paulo (UNOESTE), are contained in Figure 2. 


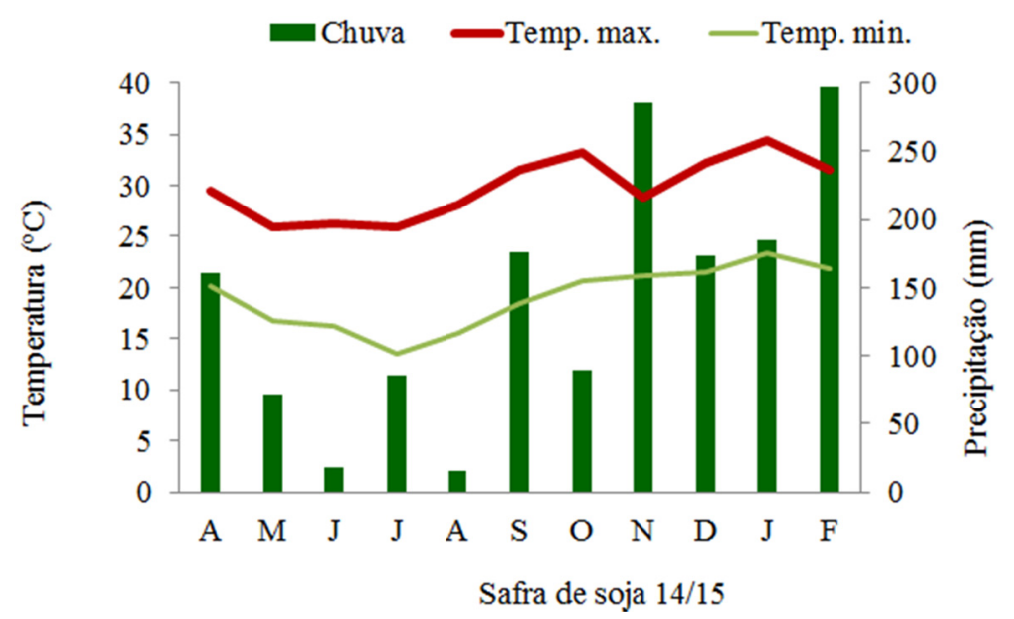

Figure 2. Rainfall and minimum and maximum monthly temperature between April 2014 and February 2015

\subsection{Experimental Design and Treatments}

The experimental design it was constituted for two blocks each for the study variable: soil scarification, no soil scarification. Each block was divided into 4 sub-blocks/treatments (control-natural seed bank of Urochloa brizantha; Urochloa brizantha broadcast seeding; Urochloa brizantha in line seeding; Urochloa brizantha in line seeding with soybean intercropped) with four replicates.

Table 1. The experimental design adopted, with description of blocks and subblocks

\begin{tabular}{lll}
\hline Block & Sub-blocks & Replications \\
\hline 1. No Soil Scarification & T-NSB (Control) & $\mathbf{4}$ \\
& T2 -NSB + Broadcast seeding & $\mathbf{4}$ \\
& T3-NSB + Seeding in line & $\mathbf{4}$ \\
& T4-NSB + Seeding in line intercropped soybean & $\mathbf{4}$ \\
\hline 2. Soil Scarification & T-NSB (Control) & $\mathbf{4}$ \\
& T2-NSB + Broadcast seeding & $\mathbf{4}$ \\
& T3-NSB + Seeding in line & $\mathbf{4}$ \\
\hline
\end{tabular}

Note. NSB (natural seed bank); Urochloa brizantha (cv. Marandu) were sowed $4 \mathrm{~kg} \mathrm{ha}^{-1}$.

For the implementation of T3 and T7 treatments, the John Deere seeder was used-seven rows with $0.45 \mathrm{~m}$ spacing. For T4 and T8 implantation, two operations were carried out, the first for sowing the forage and the other for soybean sowing.

Before the implementation of the experiment, the soil chemical characterization was performed at a depth of $0-20 \mathrm{~cm}$.

\subsection{Installation and Conduction of the Experiment}

Table 2. Chemical analysis of the soil before the implantation of the experiment

\begin{tabular}{|c|c|c|c|c|c|c|c|c|c|c|c|c|c|}
\hline Prof. & $\mathrm{pH}$ & M.O. & $\mathrm{P}$ & $\mathrm{SO}_{4}{ }^{2-}$ & $\mathrm{Al}^{3+}$ & $\mathrm{H}+\mathrm{Al}$ & $\mathrm{K}$ & $\mathrm{Ca}$ & $\mathrm{Mg}$ & SB & CTC & $\mathrm{m}$ & $\mathrm{V}$ \\
\hline $\mathrm{cm}$ & & $\mathrm{g} \mathrm{dm}^{-3}$ & \multicolumn{2}{|c|}{--- $\mathrm{mg} \mathrm{dm}^{-3}$--- } & $\begin{array}{c}--- \\
\end{array}$ & - & ---- & $\mathrm{mol}_{\mathrm{c}} \mathrm{dr}$ & 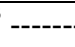 & - & ------ & \multicolumn{2}{|c|}{----- \% ----- } \\
\hline $0-20$ & 5.2 & 11.5 & 1.7 & 6.2 & 0 & 19.6 & 0.9 & 10.1 & 9.1 & 20.1 & 39.6 & 0 & 50.6 \\
\hline
\end{tabular}

The following parameters were determined: organic matter, $\mathrm{P}$ (resin), $\mathrm{K}, \mathrm{Ca}, \mathrm{Mg}, \mathrm{pH}$ and $(\mathrm{H}+\mathrm{Al})$, total cation exchange capacity (CTC) and base saturation. After the chemical characterization of the soil, limestone and 
gypsum will be applied (Raij et al., 1997). The scarification of the area was performed after the application of the limestone in the depth of $30 \mathrm{~cm}$.

The desiccation of degraded pasture was carried out in April 2015. The re-sowing of Urochloa brizantha grass was carried out at the end of April 2015. The soybean cultivar used was TMG 1264 RR, which was sown at the beginning of the month of November, 2015. The seed treatment was carried out with the agrochemicals Standak ${ }^{\circledR}$ Top (Fipronil) in the dosages $2.4 \mathrm{~L} \mathrm{ha}^{-1}$, containing germination: $80 \%$ and minimum purity: $99 \%$ the soybean seeds. The fertilization of sowing was with $260 \mathrm{~kg} \mathrm{ha}^{-1}$, using the formulation 043010 , a cover fertilization with potassium chloride was also carried out, the first one being at 20 DAE (days after emergence) at the dosage of $125 \mathrm{~kg} \mathrm{ha}^{-1}$.

The equipment used to apply the liquid inoculant doses was coupled to the header of the seed drill, it has a tank with a capacity of 200 liters and has a constant stirrer, providing a better homogenization of the solution. The inoculant was released when the seed drill touches the soil and starts the sowing process, in this way, the solution is injected in all the sowing grooves at the same time, without application failures. This solution was applied at a dosage of $50 \mathrm{~L} \mathrm{ha}^{-1}$.

\subsection{Parameters Evaluated}

\subsubsection{Soil Chemical Analysis (0-20)}

A soil sampling of each treatment was performed, after homogenization $300 \mathrm{~g}$ were retained for the chemical analysis of fertility in the UNOESTE soil analysis laboratory according to Raij's methodology (2011).

\subsubsection{Forage Dry Matter Yield}

Samples were collected in an area of $0.15 \mathrm{~m}^{2}$ (four replicates) to determine the shoot dry matter yield. The collection was carried out five months after sowing of the pasture, randomly within the useful area of the plots. The plants were dried in an oven with forced circulation of air and temperature of $60-70{ }^{\circ} \mathrm{C}$ until reaching constant mass (dry matter determination). After drying, the samples were milled in a Willey type mill, for analysis and nutritional analysis.

\subsubsection{Components of Soy Production}

Plant population: It was performed before harvest, the plants were counted in a central row with a length of $5 \mathrm{~m}$ in each replicate, and the results were converted into $\mathrm{ha}^{-1}$ plants.

Number of pods per plant: At the time of harvest, 10 plants were collected, followed by four replications, in which the number of pods per plant were determined by the relation between total number of pods and the total number of plants.

Number of grains per pod: It was determined by the relation between total number of grains and the total number of pods, evaluating the 10 plants collected to determine the number of pods per plant.

Weight of 100 grains $(\mathrm{g})$ : It was evaluated by weighing three samples of 100 grains each in each plot. The data obtained were transformed to a moisture content of $130 \mathrm{~g} \mathrm{~kg}^{-1}$.

\subsubsection{Yield of Soybeans}

The plants were harvested with a Jumil JM390 Grain Harvester, and the total harvested from each replicate of the plot was $3.6 \mathrm{~m}^{2}$. After this operation, the grains were weighed and the grain yield, in $\mathrm{kg} \mathrm{ha}^{-1}$, corrected for water content of $130 \mathrm{~g} \mathrm{~kg}^{-1}$ was calculated.

\section{Results and Discussion}

It can be observed in Table 3 that the results of dry matter yield of the forage showed only significant values when compared to different types of pasture reimplantation, that is, the highest values were found in the sowing to the line and to the line consorted with soybean, in which the biological fixation of nitrogen (BFN) was the function. In contrast, there was no significant response to the different forms of soil management (with and without scarification). It has been proven that scarification is not the best method to prepare soil for pasture. According to Kunz et al. (2013) scarification of the soil in crop-livestock integration under no-till system, did not provide favorable physical-water conditions for the development of plants. The focus of the study was to evaluate soybean benefits to the palisade grass, but there are studies that focus on soybean grain harvest. Crusciol et al. (2014) verified that intercropped soybean with palisade grass did not significantly affect soybean grain yield. This is important, after the soybean harvest the palisade grass will be already established and will take the remaining nutrients of the fertilization. 
Table 3. Dry matter yield (DMY) of forages in different pasture reimplantation systems, with and without scarification

\begin{tabular}{ll}
\hline Treat. & DMY $\left(\mathbf{k g ~ h a} \mathbf{~ a}^{-\mathbf{1}}\right)$ \\
\hline NSB & $4.75 \mathrm{~b}$ \\
NSB + Broadcast seeding & $5.24 \mathrm{~b}$ \\
NSB + Seeding in line & $6.37 \mathrm{a}$ \\
NSB + Seeding in line intercropped soybean & $6.29 \mathrm{a}$ \\
\hline CV\% & 20.15 \\
\hline Scarification & \\
\hline Soil scarification & 5.6 \\
No soil scarification & 5.8 \\
\hline CV\% & 10.66 \\
\hline & Probability (P $\geq \mathbf{F})$ \\
\hline Sist. (S) & 0.001 \\
Scarif. (SC) & 0.420 \\
S*SC & 0.556 \\
\hline
\end{tabular}

Note. Terms with the same letter in the lines do not differ by the Tukey test $(\mathrm{P} \leq 0.05)$. NSB: natural seed bank.

In the evaluations of soy production and yield components, scarification treatment and treatment without scarification, did not express significant differences (Table 4), that could improve the production and yield of the soybean. Several studies show that the scarification did not improve soybean yield production. Recently, Seidel et al. (2018) observed that the scarification benefits did not persist and did not increase the soybean grain production.

The results of the different pasture reimplantation systems had little influence over these components, primarily only affecting, soybean yield, which expressed a significant increase when forage sowing was used in a consortium with soybean (Table 4). The definition of soybean yield occurs from the interaction between the plant, the environment and the management (Cavalcante et al., 2009). Other benefits can be obtained with the consortium between soybean and pasture. One of the most effective practices to obtain high yields in a production system, is the consortium of soybean with grass, thus providing a great saving of nitrogen fertilization due to the great capacity that the soybean has, to perform biological nitrogen fixation (Macuri, 2008). According to Machado et al. (2017), soybean intercropped with palisade grass contributes to controlling weed growth and, in general, does not reduce soybean yield.

Table 4. Production and yield components of soybeans in different forms of pasture reimplantation with and without scarification

\begin{tabular}{llllll}
\hline Treat. & $\begin{array}{l}\text { Pop. } \\
\left(\text { Plant }^{-1}\right)\end{array}$ & $\begin{array}{l}\text { Pod } \\
\left(\mathrm{n}^{\circ} \text { plant }^{-1}\right)\end{array}$ & $\begin{array}{l}\text { Grain } \\
\left(\mathrm{n}^{\circ} \text { vagem }\right)\end{array}$ & $\begin{array}{l}\text { Weight } \\
(100 \text { grain })\end{array}$ & $\begin{array}{l}\text { Yield } \\
\left(\mathrm{Kg} \mathrm{h}^{-1}\right)\end{array}$ \\
\hline NSB & 12.175 & 34.437 & 2.122 & 14.409 & $1.766 \mathrm{~b}$ \\
NSB+Broadcast Seeding (BS) & 12.787 & 30.375 & 2.066 & 14.574 & $1.883 \mathrm{~b}$ \\
NSB+Seeding in line (SL) & 13.712 & 28.825 & 2.162 & 14.630 & $2.018 \mathrm{ab}$ \\
NSB+Seeding in line Intercropped soybean & 13.850 & 29.987 & 2.090 & 14.719 & $2.243 \mathrm{a}$ \\
\hdashline CV\% & 10.07 & 26.50 & 7.28 & 7.63 & 8.50 \\
\hline Scarification & & & & & \\
Soil scarification & 13.162 & 28.194 & 2.166 & 15.267 & 35.033 \\
No soil scarification & 13.100 & 33.619 & 2.054 & 13.898 & 30.899 \\
\hline CV\% & 15.83 & 43.71 & 17.21 & 9.03 & 12.96 \\
\hline Sist. (S) & 0.096 & 0.339 & 0.448 & 0.060 & 0.001 \\
Scarif. (SC) & 0.938 & 0.568 & 0.637 & 0.952 & 0.715 \\
S*SC & 0.074 & 0.442 & 0.069 & 0.079 & 0.041 \\
\hline
\end{tabular}

Note. Terms with the same letter in the lines do not differ by the Tukey test $(\mathrm{P} \leq 0.05)$. NSB: natural seed bank. 


\section{Conclusion}

Considering the results obtained in the following research, it can be concluded that, according to the different pasture reimplatation systems, the treatment (in-line + soybean) contributed both to the increase of the dry matter of fodder and to a yield of Soybean.

Regarding the effect of soil scarification, none of the results were significantly influenced.

\section{References}

Alves, A. G. C., Cogo, N. P., \& Levien, R. (1995). Relationship of soil erosion with persistence of dead vegetation cover. Brazilian Journal of Soil Science, 19, 127-132.

Asmus, G. L., \& Andrade, P. J. M. (2001). Reproduction of the gnarl nematode (Meloidogyne javanica) in some alternative plants for use in succession to the soybean crop. Embrapa Agropecuária Oeste, Technical Communication, 37 (p. 4). Dourados: Embrapa Agropecuária Oeste.

Brum, A. L., Heck, C. R., Lemes, C. L., \& Müller, P. K. (2005). The world soybean economy: impacts on the oilseed production chain in Rio Grande do Sul 1970-2000 (Annals of Congresses). XLIII Sober Congress in Ribeirão Preto, São Paulo.

Camara, R. K., \& Klein, V. A. (2005). Ecarification in no-tillage as a soil and water conservation technique. Revista Brasileira de Ciência do Solo, 29, 789-796. https://doi.org/10.1590/s0100-06832005000500014

Cavalcante, A. K., Espindola, S. M. C. G., Bisinotto, F. F., Costa, E. G., Lima, P. C., \& Finholdt, R. A. (2009). Selection and evaluation of soybean strains in the second year of planting in relation to oil and protein content. VIII Scientific Journey of Fazu.

Crusciol, C. A. C., Nascente, A. S., Mateus, G. P., Pariz, C. M., Martins, P. O., \& Borghi, E. (2014). Intercropping soybean and palisade grass for enhanced land use efficiency and revenue in a no till system. European Journal of Agronomy, 58, 53-62. https://doi.org/10.1016/j.eja.2014.05.001

Dall'gnol, A. (2000). The impact of soybeans on the Brazilian economy. Technical information for agriculture. São Paulo: Agricultural Machines Jacto.

Farias, J. R. B., et al. (2001). Characterization of water deficit risk in soybean producing regions in Brazil. Rev. Bras. Agrometeorology, 9(3), 415-421.

Ferreira, D. F. (2011). Sisvar: A computer statistical analysis system. Science \& Agrotechnology, Lavras, 35(6), 1039-1042. https://doi.org/10.1590/s1413-70542011000600001

Franchini, J. C., Meda, A. R., Cassiolato, M. E., Miyazawa, M., \& Pavan, M. A. (2001). Potential of extracts of vegetal residues in the mobilization of limestone in the soil by biological methods. Sci. Agric., 58(2), 357-360. https://doi.org/10.1590/s0103-90162001000200020

Freitas, P. L. de, Blancaneaux, P., Gavinelli, E., Larré-Larrouy, M. C., \& Feller, C. (2000). Level and nature of the organic stock of latosols under different systems of use and management. Pesquisa Agropecuária Brasileira, 35, 157-170. https://doi.org/10.1590/s0100-204×2000000100018

Hungary, M., Campo J. C., \& Mendes, I. C. (2001). Biological nitrogen fixation in soybean crop. Embrapa soybean (p. 48).

Hungary, M., Vargas, M. A. T., Suhet, A. R., \& Peres, J. R. R. (1994). Biological fixation of nitrogen in soybean. In R. S. Araújo, \& M. Hungary (Eds.), Microorganisms of agricultural importance (pp. 9-89). Brasília: Embrapa-SPI.

Igue, K. (1984). Dynamics of organic matter and its effects on soil properties. Green fertilization in Brazil (pp. 232-267). Campinas: Cargill Foundation.

Kluthcouski, J., \& Cordeiro, L. A. M. (2016). Sustainable production in soils. Retrieved May 10, 2016, from $\mathrm{http}: / /$ www.solosarenosos.com.br/deta les-noticia/producao-sustentavel-nos solos-arenosos

Kochhann, R. A., \& Denardin, J. E. (2000). Implementation and management of the no-tillage system.

Kunz, M., Araujo Gonçalves, A. D. M., Reichert, J. M., Locks Guimarães, R. M., Reinert, D. J., \& Rodrigues, M. F. (2013). Soil compaction in the soybean-livestock integration of milk in clayey Latosol with direct seeding and scarification. Brazilian Journal of Soil Science, 37, 1699-1708. https://doi.org/10.1590/ S0100-06832013000600026 
Machado, L. A. Z., \& Assis, P. G. G. (2010). Production of straw and fodder by annual and perennial species in succession to soybean. Brazilian Agricultural Research, 45, 415-422. https://doi.org/10.1590/s0100-204x 2010000400010

Machado, L. A. Z., Cecato, U., Comunello, E., Concenço, G., \& Ceccon, G. (2017). Establishment of perennial forage in a consortium with soybean, for integrated agricultural production systems. Brazilian Agricultural Research, 52, 521-529. https://10.1590/S0100-204X2017000700006

Macuri, R. (2008). The rotation of crops as a tool to control agricultural pests. Team ReHAgro. Retrieved April 5, 2008, from http://www.rehagro.com.br/siterehagro/publicaçãodocdnoticia=1389

Marchão, R. L., Balbino, L. C., Silva, E. M. da, Santos Junior, J. de D. G., Sá, M. A. C., Vilela, L., \& Becquer, T. (2007). Physical quality of a Red Latosol under crop-livestock integration systems in the Cerrado. Brazilian Agricultural Research, 42, 873-882. https://doi.org/10.1590/s0100-204x2007000600015

Miyazawa, M., Pavan, M. A., \& Franchini, J. C. (2000). Neutralization of the acidity of the soil profile by plant residues. Inf. Agron., 92, 1-8.

Miyazawa, M., Pavan, M. A., \& Franchini, J. C. (2002). Evaluation of plant residues on the mobility of surfasse applied lime. Braz. Arch. Biol. Technol., 45(3), 251-256. https://doi.org/10.1590/S1516-8913200200 0300001

Monquero, P. A., Amaral, L. R., Inacio, E. M., Brunhara, J. P., Binha, D. P., Silva, P. V., \& Silva, A. C. (2009). Effect of green manure on suppressing weed species. Plant Daninha, 27(1). https://doi.org/10.1590/ s0100-83582009000100012

Pacheco, L. P., Pires, F. R., Monteiro, F. P., Procópio, S. de O., Assis, R. L., Cargnelutti Filho, A., ... Petter, F. A. (2009). Soybean overgrowth as a technique to suppress the emergence of weeds. Plant Daninha, 27, 455-463. https://doi.org/10.1590/s0100-83582009000300005

Pitelli, R. A., \& Pitelli, R. L. C. M. (2004). Weed biology and ecophysiology. In L. Vargas, \& E. S. Romam (Eds.), Weed management and control manual (pp. 29-56). Bento Gonçalves: Embrapa Grape and Wine.

Raij, B. V. (2011). Soil fertility and nutrient management (p. 420). Piracicaba: International Plant Nutrition Institute.

Raij, B. V., Cantarella, H., Quaggio, J. A., \& Furlani, A. M. C. (1997). Technical Bulletin 100: Recommendations of fertilization and liming for the State of São Paulo (2nd ed.). Campinas, SP: Instituto Agronômico de Campinas.

Reichert, J. M., Kaiser, D. R., Reinert, D. J., \& Riquelme, F. B. (2009). Temporal variation of soil physical properties and root growth of common bean in four management systems. Brazilian Agricultural Research, 44, 310-319. https://doi.org/10.1590/s0100-204x2009000300013

Seidel, E. P., Schneider, A. P. H., Sustakowski, M. C., Matté, L. M., Mottin, M. C., \& Silva, J. H. (2018). Soybean Yield, Soil Porosity and Soil Penetration Resistance under Mechanical Scarification in No-Tillage System. Journal of Agricultural Science, 10, 268-277. https://doi.org/10.5539/jas.v10n4p268

Silva, A. C., Lima, E. P. C., \& Batista, H. R. (2010). The importance of soybean for Brazilian agribusiness: An analysis under the focus of production, employment and export. Retrieved from http://www.apec.unesc.net/ $\mathrm{V}$ _EEC/sessoes_tematicas/Economia_rural_e_agricultura_familiar

Toledo-Souza, E. D., Silveira, P. M. da, Lobo Junior, M., \& Café Filho, S. C. (2008). Soil Density and Soil Pathogens Survival. Pesquisa Agropecuária Brasileira, 43, 971-978. https://doi.org/10.1590/S0100-204X 2008000800004

Vazquez, E. V., \& De Maria, I. C. (2003). Influence of the tillage on the roughness of the soil and the retention of water in a Ferrasol. Brazilian Congress of Science of Solo, 29. Ribeirão Preto, Brazilian Society of Soil Science.

Wendling, B., Jucksch, I., Mendonça, E. de S., \& Neves, J. C. L. (2005). Organic carbon and stability of aggregates of a Red Latosol under different management. Brazilian Agricultural Research, 40, 487-494. https://doi.org/10.1590/s0100-204x2005000500010 


\section{Copyrights}

Copyright for this article is retained by the author(s), with first publication rights granted to the journal.

This is an open-access article distributed under the terms and conditions of the Creative Commons Attribution license (http://creativecommons.org/licenses/by/4.0/). 